\title{
Correspondence
}

\section{River Meuse suspended sediment yield: a new estimate and past estimates revisited by P.J. Ward}

\section{A reply to Prof. A. Pissart, by P.J. Ward}

Institute for Environmental Studies (IVM), Faculty of Earth and Life Sciences, VU University Amsterdam, De Boelelaan 1087, 1081 HV Amsterdam, the Netherlands. Email: philip.ward@ivm.vu.nl

\section{Response}

In his response to my original paper (Ward, 2008), Prof. Pissart raises a number of interesting points that require clarification in this response. I would like to thank Prof. Pissart for the detailed attention given to the paper.
With regards to the increase in suspended sediment yield reported by Close-Lecocq et al. (1982) and Lemin et al. (1987) possibly being the result of interannual variability, this occurs due to the fact that the measurements in those studies (and those of Spring and Prost, 1883) were taken for (at most) one year. Hence, even if we were to assume that these three 
Prof. Pissart states that some of the differences observed between the studies probably result from the different methods used to extract and analyse the samples of suspended sediment concentration. I agree that this probably causes some of the differences. However, as the method used at Eijsden remained constant over the period 1995-2005, differences in measuring techniques used there cannot account for the huge interannual variability at Eijsden.

The theory put forward by Lemin et al. (1987) to explain the increase in suspended sediment yield which they noted is that the canalisation of the Meuse along its entire reach between 1883 and 1980 would have prevented the deposition of sediments on the floodplain in all but the largest floods, and hence the suspended sediment concentration in the river would increase. This explanation is not mentioned in my original paper. Nevertheless, I did briefly discuss a number of parameters (land use change and rainfall erosivity) that may have caused an overall decrease in sediment erosion and the delivery of those sediments to river channels. As stated by Prof. Pissart, this discussion would therefore have benefited from a consideration of the possible effects of canalisation. I acknowledge that this may quite plausibly have led to a decrease in sedimentation on the floodplains, and hence increased sediment concentrations in the river. Although Close-Lecocq et al. (1982) did provide a short calculation on the importance of sedimentation on the alluvial plain between Namur and Liège, they also state that little is known as to the rate of sedimentation on the alluvial plain over the last century. It would be extremely useful to carry out further detailed geomorphological fieldwork in the floodplains, to quantify what effects the canalisation has had on the suspended sediment yield of the Meuse.

\section{Acknowledgements}

Many thanks to Prof. Dr Jef Vandenberghe for the useful discussions with regards to this response.

\section{References}

Close-Lecocq, J.F., Pissart, A. \& Koch, G., 1982. Les transports en suspension et en solution de la Meuse à Liège et à Tailfer (amont de Namur). Bulletin de la Société Géographique de Liège 18: 5-18.

Lemin G., Koch, G., Hurtgen, C. \& Pissart, A., 1987. Les transports en suspension de la Meuse, l'0urthe et la Höegne. Bulletin de la Société Géographique de Liège 22-23: 39-61.

Spring, W. \& Prost, E., 1883. Étude sur les eaux de la Meuse. Annales de la Société géologique de la Belgique 11: 123-220.

Ward, P.J., 2008. River Meuse suspended sediment yield: a new estimate and past estimates revisited. Netherlands Journal of Geosciences 87(2): 189-193. 